\title{
Okul Öncesi Öğretmen Adaylarının Temel Bilimsel Okuryazarlık Düzeyleri İle Bilimsel Tutumlarının İncelenmesi
}

\section{Investigation of Basic Scientific Literacy Levels and Scientific Attitudes of Prospective Pre-School Teachers}

\author{
Murat BARTAN* \\ • Geliş Tarihi: 24.02.2019 • Kabul Tarihi: 10.10.2019 • Çevrimiçi Yayın Tarihi: 10.10.2019
}

\section{Öz}

$\mathrm{Bu}$ araştırma okul öncesi öğretmen adaylarının temel bilimsel okuryazarlığı ile bilimsel tutum düzeylerinin incelenmesi amacı ile yapılmıştır. Araştırma nicel araştırma türünde tarama modeli benimsenerek gerçekleştirilmiştir. Araştırmaya, 2018-2019 eğitim öğretim yılında bir devlet üniversitesinde okul öncesi öğretmenliği anabilim dalında eğitimine devam eden 251 kadın, 37 erkek toplam 288 okul öncesi öğretmen adayı katılmıştır. Veriler temel bilimsel okuryazarlık ölçeği ve bilimsel tutum ölçeği ile toplanmıștır. Verilerin analizinde tanımlayıcı istatistikler (frekans, yüzde, ortalama) ile Anova, T-testi ve korelasyon analizleri kullanılmıştır. Araştırma sonucunda, okul öncesi öğretmen adaylarının temel bilimsel okuryazarlık seviyelerinin, kabul edilen ortalama puanın üstünde olduğu ve temel bilimsel okuryazarlık düzeylerinin yüksek olduğunu görülmüştür. Okul öncesi öğretmen adaylarının bilimsel tutum düzeylerinin de orta düzeyde olduğu görülmüştür. Okul öncesi öğretmen adaylarının hem temel bilimsel okuryazarlık ortalama puanlarının hem de bilimsel tutum ortalama puanlarının cinsiyet değişkenine göre ve bilimsel tutum ortalama puanlarının sınıf düzeylerine göre anlamlı farkllılı gösterdiği belirlenmiştir. Araştırmada okul öncesi öğretmen adaylarının temel bilimsel okuryazarlık toplam puanları ile bilimsel tutum toplam puanları arasında pozitif yönde anlamlı bir ilişki olduğu tespit edilmiştir.

Anahtar sözcükler: bilimsel okuryazarlık, bilimsel tutum, okul öncesi öğretmen adayları

Atuf:

Bartan, M.(2020). Okul öncesi öğretmen adaylarının temel bilimsel okuryazarlık düzeyleri ile bilimsel tutumlarının incelenmesi. Pamukkale Üniversitesi Eğitim Fakültesi Dergisi, 49, 293-308. doi: 10.9779/pauefd.531635

\footnotetext{
Dr. Öğr. Üyesi, Kütahya Dumlupınar Üniversitesi. Eğitim Fakültesi. Temel Eğitim Bölümü. murat.bartan@dpu.edu.tr https://orcid.org/0000-0003-2947-5643
} 


\begin{abstract}
The purpose of this study is to analyze basic science literacy and the scientific attitude level of prospective pre-school teachers. For this purpose, scientific literacy and scientific attitude levels of prospective teachers are analyzed for certain variables. In this study, the survey model is adopted. This study is conducted in the 2018-2019 academic year. A total of 288 prospective pre-school teachers among which 251 are female and 37 are male at a public university, Pre-School Teaching department participated in this study. Data collection tools; Test of Basic Scientific Literacy (TBSL) and Scientific Attitude Scale. The findings indicated that basic scientific literacy levels of prospective preschool teachers are above the acceptable average score. It is determined that prospective pre-school teachers had above average scores in basic scientific literacy scale sub-dimensions. According to scientific attitude scale total scores, the current findings noticed that the scientific attitude level of prospective pre-school teachers is a medium level. It is seen that both basic scientific literacy average scores and scientific attitude average scores of prospective pre-school teachers had a significant difference for gender variable. It is determined that there is a positive, significant relationship between basic scientific literacy total scores and scientific attitude total scores of prospective pre-school teachers.
\end{abstract}

Keywords: scientific literacy, scientific attitude, prospective pre-school teachers

\title{
Cited:
}

Bartan, M. (2020).Investigation of basic scientific literacy levels and scientific attitudes of prospective pre-school teachers. Pamukkale Üniversitesi Eğitim Fakültesi Dergisi, 49, 293-308. doi: 10.9779 /pauefd.531635 


\section{Giriş}

Bilimsel okuryazarlık kavramı ilk olarak 1958 yılında Hurd (Turgut, 2005) tarafindan ele alınmasından günümüze kadar güncelliğini yitirmemiş, bilimsel araştırmalara konu olmuş bir kavramdır. Bilim ve teknoloji alanındaki hızlı ilerleme birçok ülkede, bilim okuryazarlığını ön plana çıkarmıştır. Ülkemizde de temel okuryazarlık oranının \% 96 (MEB, 2018) gibi bir düzeye ulaşması ile bu hedef yerini bilim okuryazarlığını yükseltmeye bırakmıştır. Bilimsel okuryazarlık kavramı günümüzde 21. yüzyıl becerilerinin temelini oluşturması açısından ayrıca önemli görülmektedir.

Miller (1983) bilimsel okuryazarlığı tanımlarken 3 boyuttan bahsetmektedir. İlk boyut, bilimin kurallarının ve yöntemlerinin anlaşılması (Örneğin: bilimin doğası). İkincisi, en temel kavramların anlaşılması (Örneğin: fenin içerik bilgisi). Son olarak bilimin topluma etkisini anlama ve bunun farkında olmak şeklinde ifade edilmektedir (Akt, Turgut, 2005). Bilimsel okuryazar bir bireyin özelliklerine bakıldığında, bilim ve toplum arasındaki ilişkileri anlayabilen; bilim insanlarının çalışma etiğini anlayabilen; bilimin doğasını anlayabilen; fendeki temel kavramları anlayabilen; fen ve teknoloji arasındaki farkı anlayabilen ve fen ve beşeri bilimler arasındaki ilişkileri anlayabilen birey olarak ifade edilmektedir (Laugksch, 2000) Bilimsel okuryazarlık kavramının tanımı ve bilimsel okuryazar bireylerin özelliklerine bakıldığında bilim okuryazarlığı sadece bilgi ile değil, bilimsel beceri ve bilimsel tutumu da içine alan bir kavramdır. Bilimsel tutum ise bilimin karmaşık davranışsal yönüdür. Bilimi anlama ve öğrenmeye karşı duyulan arzu, eleştirel yaklaşma isteği, veri toplama ve anlamını araştırma, doğruluğunu kanıtlama isteği, aklı rehber etme, öncüllerin ve sonuçların düşünülmesi olarak ifade edilmektedir (Demirbaş ve Yağbasan, 2006).

Bilim insanları bilim okuryazarlığının ve bilimsel tutumun erken yaşlarda kazandırılması gerektiğine vurgu yapmaktadırlar. Küçük yaşlarda kazandırılacak bu becerilerde en önemli görev öğretmenlere düşmektedir. $\mathrm{Bu}$ nedenle öğretmenlerinde bilim okuryazarlık düzeyleri yüksek olmalı ve çocukların bilime karşı olumlu tutum kazanmalarını sağlayacak nitelikleri taşımalıdırlar. Araştırmalar göstermektedir ki çevrenin ve çocuk-öğretmen ilişkisinin, çocukların bilime olan ilgisini arttırmada ve bilime yönelik olumlu tutum geliştirmesinde önemli bir rolü olduğu kabul edilmektedir (Ünal ve Akman, 2006).

Çocukların bilim ile tanıştıkları ilk eğitim kademesi okul öncesi eğitimdir. Okul öncesi öğretmenlerin hem bilim okuryazarlığı yüksek düzeyde olmalı hem de çocuklara olumlu bilimsel tutum kazandırmalıdırlar. Nitekim 2013 okul öncesi eğitim programı incelendiğinde hem öğrenme merkezleri hem de bilim etkinlikleri ile bilimin önemli bir bileşen olarak ele alındığı görülmektedir. Okul öncesi eğitim sürecinde fen öğrenme merkezinde ve bilim etkinliklerinde çocukları dikkat etmeye, soru sormaya, merak etmeye, gözlemlemeye, araştırmaya, incelemeye ve keşfetmeye yönelten çalışmalar yürütülmektedir. Çocukların bu becerileri kullanmaları, çevrelerine karşı doğru tutumlar geliştirebilmeleri öğretmelerinin tutumlarının da doğru olması ile yakından ilişkilidir (MEB, 2013). Bu bağlamda okul öncesi öğretmenlerin bilimsel okuryazarlık durumları ile bilimsel tutumları incelenmesi önemli bir çalışma olarak düşünülmektedir.

Alan yazın incelendiğinde öğretmen ve öğretmen adaylarının temel bilimsel okuryazarlık düzeyleri veya diğer ifade ile temel fen ve teknoloji okuryazarlıkları hakkında yapılan çalışmalara bakıldığında araştırmaların daha çok fen bilgisi öğretmen adayları ile 
yapıldığı belirlenmiştir. Bacanak (2002), fen bilgisi öğretmen adaylarının fen okuryazarlıkları ile fen- teknoloji toplum dersinin uygulanışını değerlendirmeye yönelik yaptığı araştırmada, fen okuryazarlığında erkek öğretmen adaylarının bayan öğretmen adaylarından daha başarılı oldukları ve akademik başarı ile fen okuryazarlık seviyesi arasında anlamlı bir ilişkinin olmadığını belirtmiştir. Ulutaş (2009) fen bilgisi öğretmen adaylarının bilimsel okuryazarlık seviyelerinin ve bilime yönelik tutumlarını incelediği araştırmasında fen bilgisi öğretmen adaylarının bilimsel okuryazarlık seviyelerinin ve bilime yönelik tutumlarının yeterli düzeyde olduğu sonucuna ulaşmıştır. Tekin (2013) fen bilgisi öğretmen adaylarının bilimsel okuryazarlıkları ve eleştirel düşünme becerileri arasındaki ilişkiyi incelediği araştırmasında fen bilgisi öğretmen adaylarının bilimsel okuryazarlık ile eleştirel düşünme becerilerinde cinsiyet bakımından anlamlı düzeyde farklı1ık olmadığı; akademik başarı ile bilimsel okuryazarlık arasında ilişki bulunduğunu ifade etmiştir. Fen bilgisi öğretmen adayları ile yapılan diğer çalışmalar ise; Can (2007), Caymaz (2008), Chin (2005), Kaya ve Bacanak (2013), Kocaoğlu, (2011), Özdemir (2010), Saracaloğlu, Yenice ve Özden (2013), Tekin, Aslan ve Yağız (2016), Turgut (2005), Turgut ve Fer (2006), Yakar (2010), Yetişir (2007) yapılan araştırmalara ulaşılmıştır.

Temel bilimsel okuryazarlık konusunda yapılan araştırmalarda fen bilgisi öğretmeni adaylarından sonra en çok araştırmaya dahil edilen grubun sınıf öğretmeni adayları olduğu belirlenmiştir. Huyugüzel Çavaş (2009) sınıf öğretmenlerinin fen ve teknoloji okuryazarlıkları ile öğretim yeterliliklerinin belirlenmesi amacıyla yaptığı araştırmada sınıf öğretmenlerinin fen ve teknoloji okuryazarlık seviyelerinin yeterli olmadığını, sınıf öğretmenlerinin fen ve teknoloji öğretiminde kendilerini yeterli gördükleri sonucuna ulaşmıştır. Sınıf öğretmenliği adayları ile yapılan diğer araştırmalar, Derman, Doğu ve Gödek Altun (2008), Iş1k-Terzi (2008), Özdemir (2011) çalışmalara ulaşılırken fen bilgisi ve sınıf öğretmeni adaylarının ikisi ile birlikte yapılan araştırmalarda Lee (2001), Yetişir (2007), Yolagiden (2017), yaptıkları araştırmalar olduğu görülmüştür.

Dünya genelinde birçok ülkenin eğitim programlarında hedef olarak bilimsel okuryazarlık gösterilmektedir (Tekin, Aslan ve Yağız, 2016). Bu hedeflere ulaşmada erken çocukluk döneminde bilimsel okuryazarlık becerilerinin temellerinin atılması önemli bir yer tutmaktadır. Ülkemizde yürütülen okul öncesi eğitim programı bu becerilere alt yapı oluşturacak kazanımları içinde barındırmaktadır (MEB, 2013). Bu becerileri kazandırmak ise okul öncesi öğretmenlere düşmekte, öğretmenlerin bilimsel okuryazarlık seviyelerinin yüksek olması ve olumlu bilimsel tutumlara sahip olması gerekmektedir. Alan yazın incelendiğinde okul öncesi öğretmen adaylarının temel bilimsel okuryazarlıklarına ilişkin bir araştırmaya rastlanmamıştır.

Okul öncesi öğretmen adaylarının temel bilimsel okuryazarlıkları ile bilimsel tutumlarını inceleyen bu araştırmanın, okul öncesi eğitim alanına katkı getireceği düşünülmektedir. $\mathrm{Bu}$ araştırma okul öncesi öğretmen adaylarının temel bilimsel okuryazarlık düzeyleri ile bilimsel tutum düzeylerinin incelenmesini amaçlamaktadır. Bu bağlamda aşağıdaki sorulara cevap aranmaktadır;

1. Okul öncesi öğretmen adaylarının temel bilimsel okuryazarlık ve bilimsel tutum düzeyleri nasıl bir dağ 11 ım göstermektedir?

2. Okul öncesi ögretmen adaylarının temel bilimsel okuryazarlık ve bilimsel tutum puanları cinsiyet değişkenine göre değişmekte midir? 
3. Okul öncesi öğretmen adaylarının temel bilimsel okuryazarlık ve bilimsel tutum puanları sınıf düzeyi değişkenine göre değişmekte midir?

4. Okul öncesi öğretmen adaylarının temel bilimsel okuryazarlık ile bilimsel tutum puanları arasında bir ilişki var mıdır?

\section{Yöntem}

\section{Araştırma Modeli}

Okul öncesi öğretmen adaylarının temel bilimsel okuryazarlık düzeyleri ile bilimsel tutum düzeylerinin incelenmesini amaçlayan bu çalışmada nicel araştırma yöntemi belirlenmiş ve betimsel tarama deseni kullanılmıştır. Tarama modeli geçmişte ya da hali hazırda var olan bir durumu olduğu biçimiyle betimlemeyi amaçlayan ve araştırmaya konu olan, birey veya nesneyi, kendi koşulları içerisinde olduğu gibi tanımlamaya çalışan araştırma modeli şeklinde ifade edilmektedir (Karasar, 2005). Araştırma, 2018-2019 eğitim öğretim y1lında gerçekleştirilmiştir. Araştırmaya, bir devlet üniversitesi eğitim fakültesi okul öncesi öğretmenliği ABD'da 1., 2., 3. ve 4. sınıfta eğitim gören 251 kadın, 37 erkek toplam 288 öğretmen adayı katılmıştır. Çalışma grubu basit seçkisiz örnekleme yolu ile (Büyüköztürk, 2013) seçilmiştir.

Tablo 1. Araştırmaya katılan okul öncesi öğretmeni adaylarına ilişkin bilgiler

\begin{tabular}{lcc}
\hline Cinsiyet & $\mathbf{N}$ & $\mathbf{\%}$ \\
\hline Kadın & 251 & 87,2 \\
Erkek & 37 & 12,8 \\
Toplam & 288 & 100.0 \\
\hline Sinıf & $\mathbf{N}$ & $\mathbf{\%}$ \\
\hline 1.sinif & 90 & 31,1 \\
2. sinif & 76 & 26,4 \\
3.sinif & 55 & 19,1 \\
4.sinif & 67 & 23,3 \\
Toplam & 288 & 100.0 \\
& & \\
\hline
\end{tabular}

\section{Veri Toplama Araçları}

Kişisel Bilgi Formu; Çalışmaya katılan öğretmen adaylarının cinsiyet ve sınıf düzeylerini belirlemek için araştırmacı tarafindan hazırlanan formdur.

Temel Bilimsel Okuryazarlık Ölçeği (TBO): Temel bilimsel okuryazarlık ölçeği, 1996 yılında Laugksch ve Spargo tarafından geliştirilmiş orijinal adı 'Test of Basic Scientific Literacy'dir, Ölçek iki araştırmacı tarafından Türkçe'ye uyarlanmıştır. Turgut (2005) 38 maddesini uyarlamış, ölçeğin tamamı ise Yetişir (2007) tarafından Türkçe'ye uyarlanmıştır. Ölçek doğru-yanlış-bilmiyorum şeklinde cevaplanan toplam 110 maddelik bir ölçektir. Ölçek üç alt boyuttan oluşmaktadır. Bunlar "Bilimin Doğası" (22 madde), "Fen ve Teknolojinin Toplum Üzerindeki Etkileri" (16 madde) ve "Bilimsel İçerik Bilgisi" (72 madde) şeklindedir. Ölçeği oluşturan "Bilimin Doğası" alt testi için $\alpha=0,696$; "Bilimsel İçerik Bilgisi”" alt testi için $\alpha=0,815$; "Fen ve Teknolojinin Toplum Üzerindeki Etkileri" alt testi için $\alpha=0.622$ olarak hesaplanmıştır. Temel Fen ve Teknoloji Okuryazarlığı Testi için ise $\alpha=0,884$ olarak hesaplanmıştır Laugksch ve Spargo birinin bilimsel okuryazar kabul edilmesi için "Bilimin Doğası" boyutunda en az 13 puan, "Fen ve Teknolojinin Toplum ve Çevre Üzerindeki Etkisi" 
boyutundan en az 10 puan ve "Bilimsel İçerik Bilgisi" boyutundan en az 45 puan yani toplamda en az 68 puan alması gerektiğini belirtmişlerdir.

Bilimsel Tutum Ölçeği: 1997 yılında Moore ve Foy tarafından geliştirilmiş olup, 2006 y1lında Demirbaş ve Yağbasan tarafından Türkçe'ye uyarlaması yapılmış 40 maddeden oluşan bir ölçektir. Maddeler beşli likert tipinde oluşturulmuştur. Ölçekte yer alan maddelerden 20 tanesi olumlu, 20 tanesi olumsuz olarak belirlenmiştir. Ölçek 6 alt boyuta ayrılmıştır. Bunlar; "Bilimsel Kanunlar ve Teorik Yapısı" (6 madde), "Fen Bilimlerinin Yapıs1 ve Olaylara Yaklaşma Biçimi" (6 madde), "Bilimsel Davranışı Sergileme"(6 madde), "Fen Bilimlerinin Yapısı ve Amac1" (6 madde), "Fen Bilimlerinin Toplumdaki Yeri" (6 madde) ve "Bilimsel Çalışmaları Yapmadaki İsteklilik"(10 madde) şeklinde oluşturulmuştur. Bilimsel tutum ölçeğinin güvenirliği ile ilgili olarak, Cronbach Alfa güvenirlik katsayısı 0.76, Spearman Brown iki yarı test korelasyonu ise 0.84 olarak bulunmuştur. Ölçekten elde edilebilecek en yüksek puan 200 ve en düşük puan 40 olarak belirlenmiştir. Ölçekten alınan toplam puanlara göre; 40,0093,33 puan arası düşük, 93,34- 146,67 puan arası orta, 146,68- 200,00 puan aras1 yüksek bilimsel tutum düzeyi olarak ifade edilmiştir.

\section{Verilerin Analizi}

Araştırmadan elde edilen veriler SPSS programı ile analiz edilmiştir. Verilerin analizinde tanımlayıcı istatistikler (frekans, yüzde, ortalama) ile Anova, t-testi ve korelasyon analizleri kullanılmıştır. Verilerin normal dağılım gösterdikleri belirlenmiştir.

\section{Bulgular}

$\mathrm{Bu}$ bölümde okul öncesi öğretmen adaylarının temel bilimsel okuryazarlık ve bilimsel tutum ölçeği ile toplanan verilerin analizi sonucunda ortaya çıkan bulgulara yer verilmiştir.

Temel Bilimsel Okuryazarlık Ve Bilimsel Tutum Düzeylerine İlişsin Bulgular

Tablo 2. Öğretmen adaylarının temel bilimsel okuryazarlık ölçeği puanlarına dair betimsel istatistikler

\begin{tabular}{|c|c|c|c|c|c|c|c|}
\hline & & Alt boyutlar & $\mathbf{N}$ & $\begin{array}{l}\text { En } \\
\text { Düşük } \\
\text { Puan }\end{array}$ & $\begin{array}{l}\text { En } \\
\text { Yüksek } \\
\text { Puan }\end{array}$ & $\begin{array}{l}\text { Aritmetik } \\
\text { Ortalama } \\
(X)\end{array}$ & $\begin{array}{l}\text { Standart } \\
\text { Sapma } \\
\text { (ss) }\end{array}$ \\
\hline \multirow{7}{*}{$\begin{array}{l}\text { Temel } \\
\text { Bilimsel } \\
\text { Okuryazarlık } \\
\text { Ölçeği }\end{array}$} & \multirow{4}{*}{ BİB } & $\begin{array}{l}\text { Yeryüzü/Uzay } \\
\text { Bilimleri }\end{array}$ & 288 & 4,00 & 13,00 & 8,37 & 1,61 \\
\hline & & $\begin{array}{l}\text { Fiziksel/Kimyasal } \\
\text { Bilimler }\end{array}$ & 288 & 1,00 & 14,00 & 7,58 & 2,57 \\
\hline & & Yaşam Bilimleri & 288 & 9,00 & 22,00 & 15,88 & 2,85 \\
\hline & & Sağlık Bilimleri & 288 & 9,00 & 19,00 & 15,73 & 2,22 \\
\hline & & $\mathrm{BD}$ & 288 & 7,00 & 19,00 & 13,43 & 2,25 \\
\hline & & FTTÇ & 288 & 5,00 & 18,00 & 10,44 & 1,90 \\
\hline & & TOPLAM & 288 & 46,00 & 92,00 & 71,45 & 9,20 \\
\hline
\end{tabular}

Tablo 2 incelendiğinde okul öncesi öğretmen adaylarının temel bilimsel okuryazarlık ölçeği alt boyutları ortalama puanları; "Yeryüzü/Uzay Bilimleri" alt boyutunda ortalama puanları 8,37 olduğu, "Fiziksel/Kimyasal Bilimler" alt boyutunda ortalama puanları 7,58 olduğu, "Yaşam Bilimleri" alt boyutunda ortalama puanları 15,88 olduğu, "Sağlık Bilimleri" alt boyutunda ortalama puanları 15,73 olduğu görülmüsşür. "Bilimin Doğası" alt boyutunda ortalama puanları 13,43 olduğu, "Fen ve Teknolojinin Toplum ve Çevre Üzerindeki Etkisi" alt 
boyutunda ortalama puanları 10,44 olduğu görülmektedir. Temel bilimsel okuryazarlık ölçeği toplam puanlarına bakıldığında ise ortalama puanın 71,45 olduğu görülmektedir.

Tablo 3. Öğretmen adaylarının bilimsel tutum ölçeği puanlarına dair betimsel istatistikler

\begin{tabular}{|c|c|c|c|c|c|c|}
\hline & Alt boyutlar & $\mathbf{N}$ & $\begin{array}{l}\text { En } \\
\text { Düsuük } \\
\text { Puan }\end{array}$ & $\begin{array}{l}\text { En } \\
\text { Yüksek } \\
\text { Puan }\end{array}$ & $\begin{array}{l}\text { Aritmet } \\
\text { ik } \\
\text { Ortala } \\
\text { ma } \\
(X)\end{array}$ & $\begin{array}{l}\text { Stand } \\
\text { art } \\
\text { Sapm } \\
\text { a } \\
\text { (ss) }\end{array}$ \\
\hline \multirow{7}{*}{$\begin{array}{l}\text { Bilimsel } \\
\text { Tutum } \\
\text { Ölçeği }\end{array}$} & Bilimsel kanunlar ve teorik yapıs1 & 288 & 9,00 & 29,00 & 20,21 & 3,29 \\
\hline & $\begin{array}{l}\text { Fen bilimlerinin yapısı ve olaylara } \\
\text { yaklaşma biçimi }\end{array}$ & 288 & 16,00 & 30,00 & 26,23 & 3,06 \\
\hline & Bilimsel davranışı sergileme & 288 & 14,00 & 30,00 & 25,71 & 3,36 \\
\hline & Fen bilimlerinin yapısı ve amacı & 288 & 9,00 & 26,00 & 17,47 & 2,83 \\
\hline & $\begin{array}{l}\text { Fen bilimlerinin toplumdaki yeri ve } \\
\text { önemi }\end{array}$ & 288 & 10,00 & 30,00 & 21,81 & 3,82 \\
\hline & $\begin{array}{l}\text { Bilimsel çalışmaları yapmadaki } \\
\text { isteklilik }\end{array}$ & 288 & 10,00 & 46,00 & 29,61 & 7,30 \\
\hline & Toplam & 288 & 92,00 & 170,00 & 141,07 & 13,44 \\
\hline
\end{tabular}

Tablo 3 incelendiğinde okul öncesi öğretmen adaylarının bilimsel tutum ölçeği alt boyutları ortalama puanlarına bakıldığında "Bilimsel kanunlar ve teorik yapısı" alt boyutunda ortalama puanları 20,21 olduğu, "Fen bilimlerinin yapısı ve olaylara yaklaşma biçimi" alt boyutunda ortalama puanları 26,23 olduğu, "Bilimsel davranışı sergileme" alt boyutunda ortalama puanları 25,71 olduğu, "Fen bilimlerinin yapısı ve amacı" alt boyutunda ortalama puanlar1 17,47 olduğu, "Fen bilimlerinin toplumdaki yeri ve önemi" alt boyutunda ortalama puanları 21,81 olduğu, "Bilimsel çalışmaları yapmadaki isteklilik" alt boyutunda ortalama puanları 29,61 olduğu görülmektedir. Bilimsel tutum ölçeği toplam puanlarına bakıldığında ise ortalama puanın 141,07 olduğu görülmektedir.

\section{Temel bilimsel okuryazarlık ve Bilimsel Tutum Puanlarında Cinsiyet Değişkenine İlişsin Bulgular}

Tablo 4 incelendiğinde, temel bilimsel okuryazarlık ölçeğinden alınan puanların cinsiyet değişkeni göre ortalama puanlara bakıldığında kadın öğretmen adaylarının puan ortalamalarının erkek öğretmen adaylarının puan ortalamalarından daha düşük olduğu ve bu farklılığında istatiksel olarak anlamlı olduğu $[\mathrm{t}(286)=-2,57 ; \mathrm{p}<0.05]$ görülmüştür.

Temel bilimsel okuryazarlık ölçeği alt boyutlarında cinsiyet değişkenine göre ortalama puanlara bakıldığında ise "Yeryüzü/Uzay Bilimleri" alt boyutunda $[\mathrm{t}(286)=-2,54 ; \mathrm{p}<0.05]$, "Fiziksel/Kimyasal Bilimler" alt boyutunda $[\mathrm{t}(286)=-2,36 ; \mathrm{p}<0.05]$ "Yaşam Bilimleri" alt boyutunda [t(286)=-1,42; $<<0.05]$ "Fen ve Teknolojinin Toplum ve Çevre Üzerindeki Etkisi" alt boyutunda $[\mathrm{t}(286)=-2,57 ; \mathrm{p}<0.05]$ kadın öğretmen adaylarının puan ortalamalarının erkek öğretmen adaylarının puan ortalamalarından daha düşük olduğu ve bu farklılığında istatiksel olarak anlamlı olduğu görülmüştür. "Sağlık Bilimleri" alt boyutu $[\mathrm{t}(286)=-2,00 ; \mathrm{p}>0.05]$ ve "Bilimin Doğası" alt boyutlarında $[\mathrm{t}(286)=-0,22 ; \mathrm{p}>0.05]$ ise kadın öğretmen adaylarının puan ortalamalarının erkek öğretmen adaylarının puan ortalamalarından daha düşük olduğu ancak bu farklılığın istatiksel olarak anlamlı olmadığı görülmüştür. 
Tablo 4. Öğretmen adaylarının temel bilimsel okuryazarlık ölçeği puanlarının cinsiyete göre $t$ testi sonuçları

\begin{tabular}{|c|c|c|c|c|c|c|c|c|c|}
\hline & & Alt boyutlar & Cinsiyet & $\mathbf{N}$ & $\mathbf{x}$ & Ss & sd & $\mathbf{t}$ & $\mathbf{p}$ \\
\hline \multirow{14}{*}{$\begin{array}{l}\text { Temel } \\
\text { bilimsel } \\
\text { okuryazarlık } \\
\text { ölçeği }\end{array}$} & \multirow{8}{*}{ BİB } & \multirow{2}{*}{ Bilimleri } & Kadın & 251 & 8,28 & 1,55 & \multirow{2}{*}{86} & \multirow{2}{*}{$-2,54$} & \multirow{2}{*}{$.012 *$} \\
\hline & & & Erkek & 37 & 9,00 & 1,90 & & & \\
\hline & & \multirow{2}{*}{$\begin{array}{l}\text { Fiziksel/Kimy } \\
\text { asal Bilimler }\end{array}$} & Kadın & 251 & 7,44 & 2,57 & \multirow{2}{*}{86} & \multirow{2}{*}{$-2,36$} & \multirow{2}{*}{$.019 *$} \\
\hline & & & Erkek & 37 & 8,51 & 2,47 & & & \\
\hline & & \multirow{2}{*}{$\begin{array}{l}\text { Yaşam } \\
\text { Bilimleri }\end{array}$} & Kadın & 251 & 15,75 & 2,90 & \multirow[b]{2}{*}{86} & \multirow{2}{*}{$-2,00$} & \multirow[b]{2}{*}{.046} \\
\hline & & & Erkek & 37 & 16,75 & 2,31 & & & \\
\hline & & \multirow{4}{*}{$\begin{array}{l}\text { Sağlık } \\
\text { Bilimleri }\end{array}$} & Kadın & 251 & 15,66 & 2,18 & \multirow{2}{*}{86} & \multirow{2}{*}{$-1,42$} & \multirow[b]{2}{*}{.157} \\
\hline & & & Erkek & 37 & 16,21 & 2,42 & & & \\
\hline & $\mathrm{BD}$ & & Kadın & 251 & 13,42 & 2,29 & \multirow{2}{*}{86} & \multirow{2}{*}{$-0,22$} & \multirow[b]{2}{*}{.819} \\
\hline & & & Erkek & 37 & 13,51 & 1,99 & & & \\
\hline & \multirow{2}{*}{\multicolumn{2}{|c|}{ FTTÇ }} & Kadın & 251 & 10,35 & 1,84 & \multirow{2}{*}{86} & \multirow{2}{*}{$-2,11$} & \multirow[b]{2}{*}{$.036^{*}$} \\
\hline & & & Erkek & 37 & 11,05 & 2,17 & & & \\
\hline & \multirow{2}{*}{\multicolumn{2}{|c|}{ TOPLAM }} & Kadın & 251 & 70,92 & 9,29 & \multirow{2}{*}{86} & \multirow{2}{*}{$-2,57$} & \multirow[b]{2}{*}{$.011 *$} \\
\hline & & & Erkek & 37 & 75,05 & 7,76 & & & \\
\hline
\end{tabular}

Tablo 5. Öğretmen adaylarının bilimsel tutum puanlarının cinsiyete göre t testi sonuçları

\begin{tabular}{|c|c|c|c|c|c|c|c|c|}
\hline & Alt boyutlar & Cinsiyet & $\mathbf{N}$ & $\mathbf{x}$ & Ss & sd & t & $\mathbf{p}$ \\
\hline \multirow{14}{*}{$\begin{array}{l}\text { Bilimsel } \\
\text { tutum }\end{array}$} & \multirow{2}{*}{$\begin{array}{l}\text { Bilimsel kanunlar ve } \\
\text { teorik yapısı }\end{array}$} & Kadın & 251 & 20,09 & 3,28 & \multirow{2}{*}{286} & \multirow{2}{*}{$-1,65$} & \multirow{2}{*}{.099} \\
\hline & & Erkek & 37 & 21,05 & 3,29 & & & \\
\hline & \multirow{2}{*}{$\begin{array}{l}\text { Fen bilimlerinin yapısı } \\
\text { ve olaylara yaklaşma } \\
\text { biçimi }\end{array}$} & Kadın & 251 & 26,19 & 3,06 & \multirow[b]{2}{*}{286} & \multirow[b]{2}{*}{$-0,59$} & \multirow[b]{2}{*}{.552} \\
\hline & & Erkek & 37 & 26,51 & 3,14 & & & \\
\hline & \multirow{2}{*}{$\begin{array}{l}\text { Bilimsel davranışı } \\
\text { sergileme }\end{array}$} & Kadın & 251 & 25,67 & 3,34 & \multirow{2}{*}{286} & \multirow{2}{*}{$-0,50$} & \multirow[b]{2}{*}{.614} \\
\hline & & Erkek & 37 & 25,97 & 3,51 & & & \\
\hline & \multirow{2}{*}{$\begin{array}{l}\text { Fen bilimlerinin yapısı } \\
\text { ve amac1 }\end{array}$} & Kadın & 251 & 17,41 & 2,83 & \multirow{2}{*}{286} & \multirow{2}{*}{$-0,94$} & \multirow[b]{2}{*}{.344} \\
\hline & & Erkek & 37 & 17,89 & 2,86 & & & \\
\hline & \multirow{4}{*}{$\begin{array}{l}\text { Fen bilimlerinin } \\
\text { toplumdaki yeri ve } \\
\text { önemi } \\
\text { Bilimsel çalışmaları } \\
\text { yapmadaki isteklilik }\end{array}$} & Kadın & 251 & 21,75 & 3,84 & \multirow[b]{2}{*}{286} & \multirow[b]{2}{*}{$-0,68$} & \multirow[b]{2}{*}{.493} \\
\hline & & Erkek & 37 & 22,21 & 3,67 & & & \\
\hline & & Kadın & 251 & 29,25 & 7,32 & \multirow{2}{*}{286} & \multirow{2}{*}{$-2,23$} & \multirow[b]{2}{*}{$.026^{*}$} \\
\hline & & Erkek & 37 & 32,10 & 6,74 & & & \\
\hline & \multirow[t]{2}{*}{ Toplam } & Kadın & 251 & 140,38 & 13,26 & \multirow{2}{*}{286} & \multirow{2}{*}{$-2,28$} & \multirow[t]{2}{*}{$.023 *$} \\
\hline & & Erkek & 37 & 145,75 & 13,91 & & & \\
\hline
\end{tabular}

Tablo 5 incelendiğinde, bilimsel tutum ölçeğinden alınan puanların cinsiyet değişkeni göre ortalama puanlarına bakıldığında kadın öğretmen adaylarının puan ortalamalarının erkek öğretmen adaylarının puan ortalamalarından daha düşük olduğu ve bu farklılığında istatiksel olarak anlamlı olduğu $[\mathrm{t}(286)=-2,28 ; \mathrm{p}<0.05]$ görülmüştür.

Bilimsel Tutum ölçeği alt boyutlarında cinsiyet değişkenine göre ortalama puanlara bakıldığında ise "Bilimsel Kanunlar ve Teorik Yapısı" alt boyutunda $[\mathrm{t}(286)=-1,65 ; \mathrm{p}>0.05]$, "Fen Bilimlerinin Yapısı ve Olaylara Yaklaşma Biçimi" alt boyutunda [t(286)= $-0,59 ; \mathrm{p}>0.05]$, "Bilimsel Davranışı Sergileme" alt boyutunda $[\mathrm{t}(286)=-0,50 ; \mathrm{p}>0.05]$, "Fen Bilimlerinin Yapısı 
ve Amac1" alt boyutunda $[\mathrm{t}(286)=-0,50 ; \mathrm{p}>0.05]$ ve "Fen Bilimlerinin Toplumdaki Yeri ve Önemi" alt boyutunda [t(286) $=-0,68 ; \mathrm{p}>0.05]$ kadın öğretmen adaylarının puan ortalamalarının erkek öğretmen adaylarının puan ortalamalarından daha düşük olduğu ancak bu farklılığın istatiksel olarak anlamlı olmadığı görülmüştür. "Bilimsel Çalışmaları Yapmadaki İsteklilik" alt boyutunda cinsiyet değişkenine göre kadın öğretmen adaylarının puan ortalamalarının erkek öğretmen adaylarının puan ortalamalarından daha düşük olduğu ve bu farklılığında istatiksel olarak anlamlı olduğu $[\mathrm{t}(286)=-2,23 ; \mathrm{p}<0.05]$ görülmüştür.

Temel bilimsel okuryazarlık ve Bilimsel Tutum Puanlarında Sınıf Düzeyine İlişkin Bulgular

Tablo 6. Öğretmen adaylarının sınıf düzeylerine göre temel bilimsel okuryazarlık ölçeği toplam puanlarına ait aritmetik ortalama, standart sapma değerleri

\begin{tabular}{|c|c|c|c|c|}
\hline Ölçek & Sinıf & $\mathbf{N}$ & $\mathbf{x}$ & Ss \\
\hline \multirow{4}{*}{ Temel Bilimsel Okuryazarlık Ölçeği } & 1 & 90 & 70,66 & 9,26 \\
\hline & 2 & 76 & 71,22 & 8,28 \\
\hline & 3 & 55 & 71,43 & 9,37 \\
\hline & 4 & 67 & 72,77 & 9,99 \\
\hline
\end{tabular}

Tablo 6 incelendiğinde temel bilimsel okuryazarlık ölçeği toplam puanları ortalamalarına bakıldığında birinci sınıf öğretmen adaylarının 70.66 ortalama puana, ikinci sınıf öğretmen adaylarının 71.22 ortalama puana, üçüncü sınıf öğretmen adaylarının 71.43 ortalama puana ve dördüncü sınıf öğretmen adaylarının 72.77 ortalama puana sahip oldukları görülmektedir.

Tablo 7. Öğretmen adaylarının temel bilimsel okuryazarlık ölçeği puanlarının sınıf düzeyine göre anova sonuçları

\begin{tabular}{lllllll}
\hline & $\begin{array}{l}\text { Varyansın } \\
\text { kaynağı }\end{array}$ & Kareler toplamı & Sd & $\begin{array}{l}\text { Kareler } \\
\text { ortalaması }\end{array}$ & f & p \\
\hline & Gruplar arası & 176,953 & 3 & 58,984 & & \\
$\begin{array}{l}\text { Temel Bilimsel } \\
\begin{array}{l}\text { Okuryazarlık } \\
\text { Ölçeği }\end{array}\end{array}$ & Gruplar içi & 24130,366 & 284 & 84,966 &, 694 &, 556 \\
\hline
\end{tabular}

Tablo 7 incelendiğinde temel bilimsel okuryazarlık ölçeği ne ilişkin gruplar arasında istatistiksel olarak anlamlı bir farklılık olmadığ görülmektedir $(F=0,694, p>0,05)$.

Tablo 8. Öğretmen adaylarının sınıf düzeylerine göre bilimsel tutum ölçeği toplam puanlarına ait aritmetik ortalama, standart sapma değerleri

\begin{tabular}{|c|c|c|c|c|}
\hline Ölçek & Sinıf & $\mathbf{N}$ & $\mathbf{x}$ & Ss \\
\hline \multirow{4}{*}{ Bilimsel Tutum Ölçeği } & 1 & 90 & 137,76 & 14,05 \\
\hline & 2 & 76 & 142,40 & 12,56 \\
\hline & 3 & 55 & 139,63 & 12,57 \\
\hline & 4 & 67 & 145,17 & 13,21 \\
\hline
\end{tabular}

Tablo 8 incelendiğinde bilimsel tutum ölçeği toplam puanları ortalamalarına bakıldığında birinci sınıf öğretmen adaylarının 137,76 ortalama puana, ikinci sınıf öğretmen adaylarının 142,40 
ortalama puana, üçüncü sınıf öğretmen adaylarının 139,63 ortalama puana ve dördüncü sınıf öğretmen adaylarının 145,17 ortalama puana sahip oldukları görülmektedir.

Tablo 9. Öğretmen adaylarının bilimsel tutum puanlarının sınıf düzeyine göre anova sonuçları

\begin{tabular}{llllllll}
\hline & Varyansın kaynağı & $\begin{array}{l}\text { Kareler } \\
\text { toplamı }\end{array}$ & Sd & $\begin{array}{l}\text { Kareler } \\
\text { ortalaması }\end{array}$ & $\mathbf{f}$ & $\mathbf{p}$ & $\begin{array}{l}\text { Gruplar } \\
\text { arası } \\
\text { fark }\end{array}$ \\
\hline $\begin{array}{l}\text { Bilimsel } \\
\text { tutum } \\
\text { ölçeği }\end{array}$ & $\begin{array}{l}\text { Gruplar arası } \\
\text { Gruplar içi }\end{array}$ & 2362,435 & 3 & 787,478 & & & \\
& Toplam & 49505,033 & 84 & 174,313 & 4,518 &, 004 & $4-1$ \\
& 51867,469 & 87 & & & & \\
\hline
\end{tabular}

Tablo 9 incelendiğinde bilimsel tutum ölçeğine ilişkin gruplar arasında istatistiksel olarak anlamlı farklılıklar saptanmıştır $(\mathrm{F}=4,518, \mathrm{p}<0,05)$. Farklılıkların, hangi gruplar arasında olduğunu belirlemek amacıyla yapılan Scheffe testi analizi sonuçlarına göre, dördüncü sınıf ile birinci sınıf okul öncesi öğretmen adayı arasında farklılık gösterdiği ve bunun dördüncü sınıf öğretmen adayları lehine farklılaştığı görülmektedir.

Temel Bilimsel Okuryazarlık Ölçeği İle Bilimsel Tutum Ölçeği Arasındaki İlişkiye Yönelik Bulgular

Tablo 10. Temel Bilimsel Okuryazarlık Ölçeği İle Bilimsel Tutum Ölçeği Arasındaki İlişkiye Yönelik Korelasyon Analizi Sonuçları

\begin{tabular}{lll} 
& \multicolumn{1}{c}{ Temel Bilimsel } & Bilimsel Tutum \\
& Okuryazarlık & \\
\hline Temel Bilimsel Okuryazarlık & - & - \\
Bilimsel Tutum & $.274^{* *}$ & - \\
\hline$* * \mathrm{p}<.001$ &
\end{tabular}

Okul öncesi öğretmen adaylarının temel bilimsel okuryazarlık toplam puanları ile bilimsel tutum düzeyleri arasında nasıl bir ilişki olduğunu belirleyebilmek için yapılan pearson korelasyon analizi sonuçlarına göre, temel bilimsel okuryazarlık toplam puanları ile bilimsel tutum toplam puanları arasında pozitif yönde ve düşük düzeyde, anlamlı bir ilişki görülmektedir $(\mathrm{r}=0.274, \mathrm{p}<.001)$.

\section{Tartışma ve Sonuç}

Okul öncesi öğretmen adaylarının temel bilimsel okuryazarlık düzeyleri ile bilimsel tutum düzeyleri arasındaki ilişkiyi incelemeyi amaçlayan bu araştırmada, temel bilimsel okuryazarlık ölçeğinin toplam puanları ve alt boyutlarına ilişkin değerlendirmeler, Laugksch ve Spargo (1996) tarafından belirlenmiş kriterler dikkate alınarak yapılmıştır. Laugksch ve Spargo birinin bilimsel okuryazar kabul edilmesi için "Bilimin Doğası" boyutunda en az 13 puan, "Fen ve Teknolojinin Toplum ve Çevre Üzerindeki Etkisi" boyutundan en az 10 puan ve "Bilimsel İçerik Bilgisi" boyutundan en az 45 puan yani toplamda en az 68 puan alması gerektiğini belirtmişlerdir (Huyugüzel Çavaş, 2009). Bu kriterler dikkate alındığında yapılan araştırmada; Okul öncesi öğretmen adaylarının temel bilimsel okuryazarlık seviyelerinin, kabul edilen ortalama puanın üstünde olduğu görülmektedir. Bu sonuç okul öncesi öğretmen adaylarının temel bilimsel okuryazarlık düzeylerinin yüksek olduğunu göstermiştir. Okul öncesi öğretmen adaylarının temel bilimsel okuryazarlık alt boyutlarında da temel bilimsel okuryazarlık için 
gerekli ortalama puanların üzerinde puanlar aldıkları belirlenmiştir. Genel olarak bakıldığında, Okul öncesi öğretmen adaylarının temel bilimsel okuryazarlığa ilişkin ölçekteki soruları doğru olarak yanıtladıkları görülmüştür.

Temel bilimsel okuryazarlık ile ilgili yapılan çalışmalara bakıldığında Bacanak (2002) ile Özdemir (2010) fen bilgisi öğretmen adayları ile Işık-Terzi (2008) ve Huyugüzel Çavaş (2009) sınıf öğretmenleri ile yaptığı çalışmada temel bilimsel okuryazarlık seviyelerinin oldukça düşük olduğu sonucuna ulaşmışlardır. Tekin (2013) fen bilgisi öğretmen adayları ile Yolagiden (2017) fen bilgisi öğretmen adayları ve sınıf eğitimi öğretmen adayları ile yaptıkları çalışmada temel bilimsel okuryazarlık seviyelerinin ortalama puanların üzerinde puanlar aldığını belirlemiştir. Aynı bölüm öğrencilerinin önceki yıllarda daha düşük puanlara ulaşıp son yapılan araştırmalarda daha yüksek puan almaları her geçen yıl temel bilimsel okuryazarlık farkındalığı gelişmiş öğrencilerin yetişmesi ile ilişkili olduğu düşünülmektedir. Bilimsel tutum ölçeği toplam puanlara göre okul öncesi öğretmen adaylarının bilimsel tutum düzeylerinin orta düzeyde olduğu görülmüştür. Kılıç (2011) sekizinci sınıf öğrencileri ile yaptığı çalışmada da öğrencilerin bilimsel tutum düzeylerinin orta düzeyde olduğu sonucuna varmıştır.

Çalışmanın cinsiyet değişkeni ile ilgili bulgusuna bakıldığında, okul öncesi öğretmen adaylarının temel bilimsel okuryazarlık ölçeğinin ortalama puanlarının cinsiyet değişkenine göre anlamlı bir şekilde farklılaştığ görülmektedir. Bacanak (2002) ve Yolagiden (2017)'ın yaptığı çalışmada cinsiyete göre fark olduğunu belirtirken, Işık-Terzi (2008), Yetişîr (2007), Huyugüzel Çavaş (2009) ve Tekin (2013) yaptıkları çalışmalarda cinsiyete göre farklılıklara ulaşamamışlardır. Bu durumun nedeninin ilgili araştırmaların örneklemlerinde cinsiyete göre farklılıkların olmasının sebep olduğu düşünülmektedir

Okul öncesi öğretmen adaylarının bilimsel tutum düzeyleri cinsiyet değişkenine analiz edildiğinde kadın öğretmen adaylarının bilimsel tutum ölçeği toplam puanlarının ortalamasının erkek öğretmen adayları puanlarının ortalamasından düşük olduğu ve puanlar arasında istatistiksel olarak anlamlı bir farklılık olduğu görülmektedir. Kılıç (2011) yaptığı çalışmada da cinsiyete göre farklılıklara ulaşmıştır. Mıhladız ve Duran (2010) ilköğretim öğrencilerinin bilime yönelik tutumlarını inceledikleri çalışmalarında, öğrencilerin cinsiyetine göre bilime yönelik tutum puanları arasında anlamlı düzeyde farklılık saptamamışlardır. Bu sonuçlara göre cinsiyetin, eğitim kademesi yükseldikçe bilimsel tutum özerinde farklılık yaratan bir değişken olarak etki ettiği düşünülmektedir.

Çalışmanın sınıf düzeyi değişkeni ile ilgili bulgusuna bakıldığında okul öncesi öğretmen adaylarının bilimsel okuryazarlık seviyelerinin sınıf düzeylerine göre farklılaşmadığ 1 bulunmuştur. Yolagiden (2017) 3.sınıfta öğrenim gören öğretmen adaylarının bilimsel okuryazarlıklarının 1. ve 2. sınıfta öğrenim gören öğretmen adaylarına göre anlamlı derecede daha yüksek olduğu tespit etmiştir. Bu farklılığın yapılan araştırmanın fen bilgisi öğretmen adayları ile gerçekleştirilmiş olmasından kaynaklandığg şeklinde yorumlanmaktadır. Çünkü fen bilgisi eğitimi lisans programı derslerinin üst sınıflarda bilimsel okuryazarlık becerisine alt yapı oluşturacak kazanımlar sunduğu düşünülmektedir.

Okul öncesi öğretmen adaylarının bilimsel tutum seviyelerinin sınıf düzeyi değişkenine göre yapılan analizler sonucunda elde edilen bulgular, Okul öncesi öğretmen adaylarının bilimsel tutum düzeylerinin sınıf düzeylerine göre farklılaştı̆̆ı görülmüştür. Bulgulara 
bakıldığında dördüncü sınıf ile birinci sınıf okul öncesi öğretmen adayı arasında farklılık gösterdiği ve bunun dördüncü sınıf öğretmen adayları lehine farklılaştığı tespit edilmiştir. Bu farkın ise üniversite eğitiminin her geçen yıl öğretmen adaylarında bilimsel tutumu geliştirdiği şeklinde yorumlanmaktadır.

Temel bilimsel okuryazarlık ile bilimsel tutum puanları arasında ilişkiye yönelik sonuçlara bakıldığında; Okul öncesi öğretmen adaylarının temel bilimsel okuryazarlık düzeyleri ile bilimsel tutum arasında pozitif yönde, düşük düzeyde, anlamlı bir ilişki olduğu tespit edilmiştir. Bir başka ifade ile Okul öncesi öğretmen adaylarının temel bilimsel okuryazarlık düzeyleri artıkça bilimsel tutumları da olumlu yönde gelişmektedir.

\section{Öneriler}

Okul öncesi öğretmen adayları ile yapılan bu çalışma sonucunda şu öneriler getirilmektedir; okul öncesi öğretmen adayları ve okul öncesi öğretmenlerinin temel bilimsel okuryazarlık düzeylerini artıracak etkinliklere, eğitimlere ve seminerlere önem verilmelidir. Öğretmen adaylarının üniversite eğitimi sürecinde ve mesleğe atandıktan sonra da hem bilimsel okuryazarlık hem de olumlu bilimsel tutum kazanmalarını sağlayacak ortamlar sunulmalıdır. Çalışmanın benzeri okulöncesi öğretmenleri ile yapılabilir. Temel bilimsel okuryazarlık ile başka beceriler arasında ilişkiler incelenebilir. Öğretmen adaylarının fen ve teknoloji bilgi düzeyleri artırmaya yönelik eğitimler verile bilinir. Çalışmanın örneklemi genişletilerek daha fazla kişi ve daha farklı alanlar ile araştırmalar çeşitlendirilmelidir.

Okul Öncesi Öğretmen Adaylarının Temel Bilimsel Okuryazarlık Düzeyleri İle Bilimsel Tutumlarının İncelenmesi başlıklı çalışmanın yazım sürecinde bilimsel, etik ve alıntı kurallarına uyulmuş; toplanan veriler üzerinde herhangi bir tahrifat yapılmamış, karşılaşılacak tüm etik ihlallerde "Pamukkale Üniversitesi Eğitim Fakültesi Dergisi Yayın Kurulunun" hiçbir sorumluluğunun olmadığı, tüm sorumluluğun Sorumlu Yazara ait olduğu ve bu çalışmanın herhangi başka bir akademik yayın ortamına değerlendirme için gönderilmemiş olduğunu taahhüt ederim. 


\section{Kaynakça}

Bacanak, A. (2002). Fen Bilgisi Öğretmen Adaylarının Fen Okuryazarlıklart ile Fen- Teknoloji Toplum Dersinin Uygulanışını Değerlendirmeye Yönelik Bir Çalışma. (Yüksek Lisans Tezi). Karadeniz Teknik Üniversitesi. Fen Bilimleri Enstitüsü, Trabzon

Bacanak, A. ve Gökdere, M. (2009). Investigating level of the scientific literacy of primary school teacher candidates. In Asia-Pacific Forum on Science Learning \& Teaching. 10 (1),1-10

Büyüköztürk, Ş. (2013). Bilimsel Araştırma Yöntemleri. Ankara:Pegem.

Can, Ş. (2007). Fen Bilgisi Ö̈̆retmenliği Öğretmen Adaylarının Fen Okuryazarlık Düzeyleri Üzerine Bir Çalışma, 21. Ulusal Kimya Kongresi. İnönü Üniversitesi, Malatya.

Caymaz, B. (2008). Fen ve Teknoloji ve Sinıf Öğretmeni Adaylarının Fen ve Teknoloji Okuryazarlı̆̆ına iliş̧kin Öz Yeterlik Algıları. (Yüksek Lisans Tezi). Hacettepe Üniversitesi. Sosyal Bilimler Enstitüsü. Ankara.

Chin, C. C. (2005). First-Year Pre-service Teachers in Taiwan Do They Enter the Teacher Program with Satisfactory Scientific Literacy and Attitudes Toward Science? International Journal of Science Education, 27 (13), 1549-1570.

Demirbaş, M, ve Yağbasan, R, (2006). Fen Bilgisi Öğretiminde Bilimsel Tutumların İşlevsel Önemi ve Bilimsel Tutum Ölçeğinin Türkçeye Uyarlanma Çalışması, Uludağ Üniversitesi Eğitim Fakültesi Dergisi, 19 (2), 271-299.

Derman, A., Doğu, S. ve Gödek Altun, Y. (2008). Sinıf Öğretmenlerinin Fen ve Teknoloji Okuryazarlik Düzeyleriyle Ilgili Algllarl. 8th International Educational Technology Conference, Anadolu Üniversitesi, Eskişehir.

Huyugüzel Çavaş, P. H. (2009). Sinıf Öğretmenlerinin Fen ve Teknoloji Okuryazarlıklarl ile Öğretim Yeterliklerinin Belirlenmesi. (Doktora Tezi). Dokuz Eylül Üniversitesi. Eğitim Bilimleri Enstitüsü. İzmir.

Işık-Terzi, C. (2008). Illköğretim I. Kademede Fen ve Teknoloji Dersini Yürüten Sinı Öğretmenleri ile II. Kademede Fen ve Teknoloji Dersini Yürüten Fen Bilgisi (Fen ve Teknoloji) Öğretmenlerinin Fen Okuryazarlık Düzeylerinin Belirlenmesi ve Sonuçların Karşılaştırılması. (Yüksek Lisans Tezi), Muğla Üniversitesi. Fen Bilimleri Enstitüsü. Muğla.

Karasar, N. (2005). Bilimsel araştırma yöntemi: Ankara: Nobel Yayınevi

Kaya, M., Bacanak, A. (2013). Fen ve Teknoloji Öğretmen Adaylarının Düşünceleri: Fen Okuryazarı Birey Yetiştirmede Öğretmenin Yeri. Dicle Üniversitesi Ziya Gökalp Eğitim Fakültesi Dergisi, 21, 209-228.

Kocaoğlu, G. (2011). Fen Bilgisi Öğretmenliği Birinci ve Dördüncü Sinlf Öğretmen Adaylartnın Fen Bilgisi Başarıları, Fen Bilgisi Öğretimine Yönelik Tutumları, Üniversite Giriş Başarıları ve Not Ortalamaları Arasindaki İlişsi, (Yüksek Lisans Tezi), Uşak Üniversitesi. Sosyal Bilimler Enstitüsü. Uşak

Laugksch, R. C. (2000). Scientific Literacy: A Conceptual Overview. Science Education, 84(1), 71-94.

Lee, V. M. (2001). An Investigation of Taiwanese Graduate Students' Level of Scientific Literacy. ( PhD Thesis), The University of Texas at Austin.

Miller, J. D. (1983). Scientific Literacy: A Conceptual and Empirical Review. Daedalus, 112(2), 29-48. 
Özdemir, A. (2011). Sinıf Ögrretmenlerinin Fen ve Teknoloji Okuryazarlık Düzeylerinin İncelenmesi. (Yüksek Lisans Tezi), Uşak Üniversitesi. Sosyal Bilimler Enstitüsü. Uşak

Özdemir, O. (2010). Fen ve teknoloji öğretmen adaylarının fen okuryazarlığının durumu. Türk Fen Ĕ̈itimi Dergisi, 7(3), 42-56.

Saracaloğlu, S., Yenice, N., Özden, B. (2013). Fen Bilgisi Öğretmen Adaylarının Fen ve Teknoloji Okuryazarlığına İlişkin Öz Yeterlik Algıları İle Fene Yönelik Tutumları Arasındaki İlişki. International Journal of New Trends in Arts, Sports and Science Education, 2(1).58-69.

Tekin, N. (2013). Fen Bilgisi Öğretmen Adaylarının Bilimsel Okuryazarlı ve Eleştirel Düşünme Becerileri Arasindaki İlişkinin İncelenmesi. (Yüksek Lisans Tezi). Necmettin Erbakan Üniversitesi. Eğitim Bilimleri Enstitüsü. Konya.

Tekin, N., Aslan, O., Yağız, D. (2016). Fen bilimleri öğretmen adaylarının bilimsel okuryazarlık düzeyleri ve eleştirel düşünme. Amasya Üniversitesi Eğitim Fakültesi Dergisi, 5 (1), 23-50

Turgut, H. (2005). Yapılandırmacı Tasarım Uygulamasının Fen Bilgisi Öğretmen Adaylarının Bilimsel Okuryazarlı Yeterliklerinden "Bilimin Doğası" ve "Bilim-Teknoloji-Toplum İlişkisi" Boyutlarının Gelişimine Etkisi, (Doktora Tezi),Yıldız Teknik Üniversitesi, Sosyal Bilimler Enstitüsü. İstanbul.

Turgut, H., Fer, S. (2006). Fen Bilgisi Öğretmen Adaylarının Bilimsel Okuryazarlık Yeterliklerinin Geliştirilmesinde Sosyal Yapılandırmacı Öğretim Tasarımı Uygulamasının Etkisi. M.Ü. Atatürk Eğitim Fakültesi Ĕgitim Bilimleri Dergisi. 24,1-10

Ulutaş, Ö. (2009). Fen Bilgisi Öğretmen Adaylarının Bilimsel Okuryazarlık Seviyelerinin ve Bilime Yönelik Tutumlarının Araştırılması. (Yüksek Lisans Tezi), Orta Doğu Teknik Üniversitesi. Sosyal Bilimler Enstitüsü.Ankara.

Ünal, M. ve Akman, B., (2006). Okul öncesi öğretmenlerinin fen eğitimine karşı gösterdikleri tutumlar. H.Ü. Ĕ̈itim Fakültesi Dergisi, 30, 251-257.

Yakar, A. (2010). Türkiye'nin Bazı Üniversitelerinin Eğitim Fakültelerinde Öğrenim Görmekte Olan Fen Bilgisi Öğretmenliği 4. Sinı Öğrencilerinin Fen Okuryazarlık Düzeylerinin İstatistiksel Olarak Karşılaştırılması. (Yüksek Lisans Tezi), Muğla Üniversitesi, Fen Bilimleri Enstitüsü. Muğla.

Yenice, N, (2009). Sinıf Öğretmeni Adaylarının Fene Yönelik Tutumları ve Akademik Başarıları Arasındaki İlişki. I. Uluslararası Türkiye Eğitim Araştırmaları Kongresi (1-3 Mayıs), Çanakkale.

Yetişir, M. Ġ. 2007. İlköğretim Fen Bilgisi Öğretmenliği ve Sinı Öğretmenliği Birinci Sinıfinda Okuyan Öğretmen Adaylarının Fen ve Teknoloji Okuryazarlık Düzeyleri. (Yüksek Lisans Tezi), Gazi Üniversitesi. Eğitim Bilimleri Enstitüsü. Ankara

Yolagiden, C. (2017). Öğretmen adaylarının fen ögrenme becerisi, fen okuryazarlı̆̆ ve sosyo-bilimsel konulara yönelik tutumları arasındaki ilişsinin araştırılması, (Yüksek Lisans Tezi), Kahramanmaraş Sütçü İmam Üniversitesi, Fen Bilimleri Enstitüsü. Kahramanmaraş. 


\section{Extended Abstract}

\section{Introduction}

Scientific literacy has been an up-to-date concept that has been scientifically analyzed since 1958 when Hurd first considered this concept. At the same time, rapid advancements in science and technology field have emphasized scientific literacy in various countries. In our country, as basic literacy target ratio is highly achieved, this target has been replaced by increasing scientific literacy. Thus, under MEB 2023 vision, science literacy is considered as an important skill. According to Miller (1983), scientific literacy is defined under three dimensions: 1. Grasping scientific norms and methods (for example: nature of science). 2. Understanding key scientific terms and concepts (for example: science content information). 3. Understanding effects of science and technology on society and being aware of this effect (Laugksch, 2000).

As given in this definition, scientific literacy is not only about information but also includes scientific skills and scientific attitude. Scientific attitude is the complex behavioral aspect of science. It is the collection of willingness to understand and know, desire to question everything, data collection and analyzing meaning, desire to prove correctness, respecting logic, considering precursors, thinking results (Demirbaş and Yağbasan, 2006). Scientists emphasize the need to provide scientific literacy and scientific attitude at early ages. Teachers are the most important elements in these skills that will be provided at early ages. Therefore, teachers must have high scientific literacy level and provide positive attitude to children in terms of science. Research show that environment and relationship between child-teacher increases children's interest towards science and these have great importance to develop positive attitude towards science (Ünal \& Akman, 2006). The first education stage where children meet with science is pre-school education. Pre-school teachers should both have high scientific literacy level and provide positive scientific attitude to children.

Purpose: Purpose of this study is to analyze basic science and technology literacy and scientific attitude level of prospective pre-school teachers. For this purpose, scientific literacy and scientific attitude levels of prospective teachers are analyzed for certain variables and relationship between scientific literacy and scientific attitude is analyzed.

Research model: In this study that analyzes basic science and technology literacy and scientific attitude level of prospective pre-school teachers, survey model is adopted. This study is conducted in 2018-2019 academic year. Total of 288 prospective pre-school teachers among which 251 are female and 37 are male in Kütahya Dumlupınar University Education Faculty, Pre-School Teaching department participated to this study.

\section{Data Collection Tools}

Test of Basic Scientific Literacy (TBSL): Test of Basic Scientific Literacy was developed by Laugksch and Spargo in 1996 and this scale is adapted to Turkish by two researchers. Turgut (2005) adapted 38 items and Yetişir (2007) adapted to complete scale to Turkish. This scale is a 110 -item scale with correct-incorrect-I don't know answer options.

Scientific Attitude Scale: Scientific Attitude Scale is a 40-item scale developed by Moore and Foy in 1997 and adapted to Turkish by Demirbaş and Yaşbasan in 2006. 


\section{Results}

It is seen that basic scientific literacy levels of prospective pre-school teachers are above acceptable average score. This result shows that prospective pre-school teachers have high basic scientific literacy level. It is determined that prospective pre-school teachers had above average scores in basic scientific literacy scale sub-dimensions. Generally, it is seen that prospective pre-school teachers answered questions related with basic scientific literacy as correct. According to scientific attitude scale total scores, it is seen that scientific attitude level of prospective pre-school teachers are at medium level. It is seen that both basic scientific literacy average scores and scientific attitude average scores of prospective pre-school teachers had significant difference for gender variable. It is seen that basic scientific literacy average scores of prospective pre-school teachers had no significant difference at grade level but science attitude average scores differentiated at grade level. These findings show that there is difference between the fourth grade and first grade prospective pre-school teachers and this difference is in favor of the fourth grade prospective pre-school teachers. It is determined that there is positive, low level, significant relationship between basic scientific literacy total scores and scientific attitude total scores of prospective pre-school teachers. 